\title{
Health Care Professional
}

National Cancer Institute

\section{Source}

National Cancer Institute. Health Care Professional. NCI Thesaurus. Code C53287.

A person qualified to be eng aged in activity directed at preservation of mental and physical health by diseases prevention and treatment as a source of livelihood. 